\title{
Analysis of the use for Fire Protection Water Supply Systems in public utility buildings and residential buildings
}

\author{
Joanna Binio ${ }^{1, *}$, Sylwester Kieliszek ${ }^{1}$ \\ ${ }^{1}$ The Main School of Fire Service, Faculty of Fire Safety Engineering, 52/54 Slowackiego St., 01-629 \\ Warsaw, Poland
}

\begin{abstract}
Regulation of the Minister of Interior and Administration of 7 June 2010 on the fire protection of buildings, other construction objects and areas, presents a number of requirements that must be met by public buildings and residential buildings requirements, among others, for firefighting water supply installations. The article presents an analysis of current requirements for water supply installations in public buildings and residential buildings included in Polish legal acts. In addition, statistical data on the size of the fire are presented and real water consumption in the activities of fire protection units during events. These data were obtained from the SWD PSP program, which is the basic tool for supporting the actions of rescue and fire-fighting units. It turns out that for the objects in question statistically the largest amount of fires are small fires, where relatively little water is used. On the basis of the comparison of the actual water consumption needed to extinguish the fire by the fire department with the requirements in force in relation to the analyzed buildings, too restrictive requirements for these facilities were noticed. Appropriate efficiency of the external hydrant network ensures the possibility of carrying out extinguishing activities. In connection with the above, one should consider the legitimacy of applying high requirements for the efficiency of fire protection installations in facilities.
\end{abstract}

\section{Introduction}

One of the first steps to determine the fire safety of a building is its appropriate classification depending on the purpose and height. According to the Regulation [1] Buildings, depending on the height and number of ground storeys, are divided into low $(\mathrm{N})$, medium-high (SW), high (W) and height (WW). Due to the purpose and the way of using, it stands out: residential buildings, collective and public dwellings, which are characterized by the risk category of people (ZL I, ZL II, ZL III, ZL IV and ZL V), production and storage buildings (PM) and livestock buildings (N). The building classification has a direct impact on the detailed fire-fighting requirements for the building's construction but also on the obligation to equip it with the required fire-fighting installations.

\footnotetext{
* Corresponding author: joannabinio@sgsp.edu.pl
} 
In accordance with Regulation [2], the following water collection points are distinguished: internal hydrants with a semi-rigid hose with nominal diameter of $25 \mathrm{~mm}$ and $33 \mathrm{~mm}$ (hydrant 25 and hydrant 33), internal hydrant with a flat hose with a nominal diameter of $52 \mathrm{~mm}$ (hydrant 52) and hydrat valve without fire hose. It is commonly accepted that internal hydrants equipped with a fire hose are intended for use by the users of the object to extinguish a fiery fire, while hydrant valves 52 without additional equipment are to facilitate fire-fighting operations by the fire service [3].

In the case of analyzed public utility buildings included in the ZL category, all high and high-rise buildings should be equipped with hydrants with a semi-rigid hose with a hose diameter of $25 \mathrm{~mm}$. This provision does not apply to buildings and fire zones included in the danger category of people ZL IV, ie residential buildings. In addition, these hydrants should be used in low and medium-high buildings of the ZL I, ZL II and ZLV categories, if the fire zone exceeds $200 \mathrm{~m}^{2}$ and in ZL III low buildings with an area exceeding $1000 \mathrm{~m}^{2}$. High buildings should additionally be equipped with hydrant valves 52, allowing simultaneous water intake from the 4 most unfavorably located hydraulic valves [3]. Much lower requirements are placed on residential buildings, where the current regulations require the use of fire-fighting water supply systems with adequate power supply only in high and high-rise buildings, and this applies only to the use of hydrant valves 52 .

Detailed requirements for fire-fighting water supply systems have been specified in the Regulation of the Minister of Internal Affairs and Administration of 7 June 2010 on the fire protection of buildings, other construction objects and areas regarding the fire protection of buildings. First of all, this installation must be reliable, ensuring the water intake with the required pressure and efficiency parameters for extinguishing purposes, regardless of the operating status of other systems. The fire-extinguishing system should be supplied from an external water supply network or tanks for fire-fighting purposes with an adequate supply of water. The minimum water volume in tanks is calculated based on the assumption that the supply of internal hydrants should be provided for 1 hour. with a certain minimum efficiency. The minimum efficiency for the hydrant 25 is $1.0 \mathrm{dm}^{3} / \mathrm{s}$, for the hydrant $33-1.5$ $\mathrm{dm}^{3} / \mathrm{s}$ and $2.5 \mathrm{dm}^{3} / \mathrm{s}$. for a hydrant and hydrant valve 52 . This means that the minimum water supply for one hydrant is $3.6 \mathrm{~m} 3$. In the case of high and high-rise buildings, a total water supply for fire-fighting purposes of not less than $100 \mathrm{~m}^{3}$ should be provided. In the amendment of the regulation of 2010. a number of possibilities to reduce the capacity of these tanks to $50 \mathrm{~m}^{3}$ and $25 \mathrm{~m}^{3}$ have been indicated. The regulations allow even the abandonment of the fire protection tank in favor of supply from the water supply network with a capacity of not less than $10 \mathrm{dm}^{3} / \mathrm{s}$ for residential buildings qualified for the risk category of people ZL IV. Resignation from the use of a tank or reducing its volume requires the removal of an additional base with a diameter of $75 \mathrm{~mm}$ in the façade of the building. This base should be on the side of the fire-fighting road and enable supplying the fire-fighting water supply system with fire-fighting vehicles[2].

The introduced relaxation of the provisions on fire-fighting water supply systems, in particular reducing the requirements for the use of fire-fighting tanks is a great facilitation for designers and future owners of buildings. This applies in particular to existing buildings in which adaptation to the applicable requirements and the installation of such large water reservoirs was not possible $[4,5,6]$.

A preliminary analysis of the actual water consumption during firefighting operations indicates that the water consumption for extinguishing residential buildings is small [7]. The reduction of water consumption by fire protection units during the extinguishing of fires in residential buildings and public buildings is undoubtedly already addressed at the basic training, the so-called social aspects of fire service activities. Extinguishing activities are to be effective, but what is equally important can not generate and increase fire damages, for example by flooding lower floors. For this purpose, various techniques are 
used to supply water currents, appropriate dispersion of water in the nozzle or the use of chemical additives that increase water extinguishing efficiency. The recommended intensity of water supply for residential buildings is about $0.1 \mathrm{dm}^{3} / \mathrm{m}^{2} / \mathrm{s}$ [8]. Therefore, the current standards for fire-fighting water installations in relation to residential buildings and public buildings seem to be overstated.

\section{Analysis of real water consumption to extinguish fires in residential buildings and public buildings on the example of Warsaw}

The analysis of the actual water consumption to extinguish fires was carried out on the basis of statistical data from the ST SWD program from the KM PSP in Warsaw and from the KG PSP. This program is equipped with every fire fighting unit and is designed to support the work of PSP dispatchers and to record events in the area of a given unit. The EWID module of this program allows you to generate periodic statistics of events for a specific area.

Fires of residential buildings and public buildings account for approx $30 \%$ of all fires to which fire protection units are called. In addition, in the analyzed years, the number of fires in residential buildings was about 5 times higher than the number of fires for public buildings. Additionally, it can be noticed that the number of fires in these buildings in 2014-2016 remained at a similar level, and then in 2017 it dropped dramatically. The number of fires in 2018 is approaching the level from 2014-2016. The average amount of water used to extinguish fires in the analyzed fires in the tested time interval does not exceed $0.5 \mathrm{~m}^{3}$. For public buildings, it did not exceed even $0.25 \mathrm{~m}^{3}$. Extinguishing fires in residential buildings required the use of more water. The list of fires with the amount of water used for extinguishing is presented in Table 1.

Table 1. Summarizes the fires and water consumption for public buildings and residential buildings in the years 2014 to 2018 .

\begin{tabular}{|c|c|c|c|}
\hline \multirow{2}{*}{$\begin{array}{c}\text { Analyzed } \\
\text { year }\end{array}$} & Parameter & \multicolumn{2}{|c|}{ Type of object } \\
\cline { 2 - 4 } & & $\begin{array}{c}\text { Public } \\
\text { buildings }\end{array}$ & $\begin{array}{c}\text { Residential } \\
\text { buildings }\end{array}$ \\
\hline \multirow{4}{*}{2018} & total water consumption $\left[\mathrm{m}^{3}\right]$ & 82.07 & 771.76 \\
\cline { 2 - 4 } & number of fires & 634 & 3690 \\
\cline { 2 - 4 } & average water consumption $\left[\mathrm{m}^{3}\right]$ & 0.13 & 0.21 \\
\hline \multirow{4}{*}{2017} & total water consumption $\left[\mathrm{m}^{3}\right]$ & 71.88 & 908.92 \\
\cline { 2 - 4 } & number of fires & 254 & 1340 \\
\cline { 2 - 4 } & average water consumption $\left[\mathrm{m}^{3}\right]$ & 0.28 & 0.68 \\
\hline \multirow{3}{*}{2016} & total water consumption $\left[\mathrm{m}^{3}\right]$ & 147.13 & 1131.64 \\
\cline { 2 - 4 } & number of fires & 874.00 & 4709.00 \\
\cline { 2 - 4 } & average water consumption $\left[\mathrm{m}^{3}\right]$ & 0.17 & 0.24 \\
\hline \multirow{3}{*}{2015} & total water consumption $\left[\mathrm{m}^{3}\right]$ & 153.96 & 1646.71 \\
\cline { 2 - 4 } & number of fires & 626 & 4638 \\
\cline { 2 - 4 } & average water consumption $\left[\mathrm{m}^{3}\right]$ & 0.25 & 0.36 \\
\hline \multirow{2}{*}{2014} & total water consumption $\left[\mathrm{m}^{3}\right]$ & 57.17 & 1579.01 \\
\cline { 2 - 4 } & number of fires & 794 & 4268 \\
\hline
\end{tabular}


\begin{tabular}{l|l|l} 
average water consumption $\left[\mathrm{m}^{3}\right]$ & 0.07 & 0.37
\end{tabular}

In the analyzed buildings there was a significant advantage of small fires, for which the water consumption to extinguish fires was in the range of $0.5-1 \mathrm{~m}^{3}$. Medium and large fires occurred sporadically. Water consumption for a large fire did not exceed $50 \mathrm{~m}^{3}$. There were no very large fires. This is probably caused by a quick noticing of the fire and notification of the fire brigade. These are buildings in which people reside permanently as in residential buildings or are constantly monitored. Thanks to this, the fire does not have time to develop into bigger cubature. The comparison of the size of a fire for residential and public buildings is shown in Table 2 .

Table 2. The size of the fire for residential and public buildings in 2014-2018.

\begin{tabular}{|c|c|c|c|c|c|}
\hline \multirow{2}{*}{$\begin{array}{c}\text { The size of } \\
\text { the fire }\end{array}$} & \multicolumn{5}{|c|}{ Public buildings } \\
\cline { 2 - 6 } & $\mathbf{2 0 1 8}$ & $\mathbf{2 0 1 7}$ & $\mathbf{2 0 1 6}$ & $\mathbf{2 0 1 5}$ & $\mathbf{2 0 1 4}$ \\
\hline Small & 172 & 252 & 318 & 203 & 148 \\
\hline Average & 2 & 2 & 2 & 1 & 2 \\
\hline Big & 0 & 0 & 0 & 0 & 0 \\
\hline Very big & 0 & 0 & 0 & 0 & 0 \\
\hline
\end{tabular}

Table 3 and 4 additionally specify the types of facilities where fires occurred for public buildings and residential buildings. The largest number of fires was recorded for commercial and service buildings for which the average water consumption was about 0.5 $1 \mathrm{~m}^{3}$. In museums, libraries, archives, individual cases of fires have been recorded, which is related to the constant monitoring of these facilities and their equipping with other firefighting installations, such as fire-fighting systems or fire detection systems. A special case of fires are fires of health care buildings, hospitals for which average water consumption was below $0.2 \mathrm{~m}^{3}$. A great challenge during firefighting activities for firefighters is to organize and carry out the evacuation of a large number of patients with reduced mobility.

Table 3. Number of fires and the total amount of water needed to extinguish fires for public buildings in $2014-2018$.

\begin{tabular}{|c|c|c|c|c|c|c|c|c|c|c|}
\hline \multirow{2}{*}{ Type of object } & \multicolumn{2}{|c|}{$\mathbf{2 0 1 8}$} & \multicolumn{2}{c|}{$\mathbf{2 0 1 7}$} & \multicolumn{2}{c|}{$\mathbf{2 0 1 6}$} & \multicolumn{2}{|c|}{$\mathbf{2 0 1 5}$} & \multicolumn{2}{|c|}{$\mathbf{2 0 1 4}$} \\
\cline { 2 - 11 } & $\begin{array}{c}\mathbf{1}^{(*)} \\
{\left[\mathbf{m}^{3}\right]}\end{array}$ & $\mathbf{2}^{\mathbf{*}^{(*)}}$ & $\begin{array}{c}\mathbf{1}^{(*)} \\
{\left[\mathbf{m}^{3}\right]}\end{array}$ & $\mathbf{2}^{(*)}$ & $\begin{array}{c}\mathbf{1}^{(*)} \\
{\left[\mathbf{m}^{3}\right]}\end{array}$ & $\mathbf{2}^{\mathbf{2}^{(*)}}$ & $\begin{array}{c}\mathbf{1}^{(*)} \\
{\left[\mathbf{m}^{3}\right]}\end{array}$ & $\mathbf{2}^{(*)}$ & $\begin{array}{c}\mathbf{1}^{(*)} \\
{\left[\mathbf{m}^{3}\right]}\end{array}$ & $\mathbf{2}^{(*)}$ \\
\hline $\begin{array}{c}\text { Administrative and } \\
\text { office, banks }\end{array}$ & 4.91 & 116 & 18.59 & 176 & 8.13 & 207 & 4.3 & 144 & 17.24 & 175 \\
\hline Schools, kindergartens & 2.05 & 153 & 11 & 151 & 0.3 & 128 & 4.98 & 113 & 0.3 & 154 \\
\hline $\begin{array}{c}\text { Hospitals, } \\
\text { sanatoriums, nursing } \\
\text { homes, clinics, } \\
\text { nurseries }\end{array}$ & 1.5 & 61 & 0.1 & 72 & 2.16 & 75 & 1.03 & 56 & 0.22 & 83 \\
\hline $\begin{array}{c}\text { Shops, department } \\
\text { stores, restaurants, } \\
\text { wholesalers, service } \\
\text { establishments }\end{array}$ & 66.16 & 127 & 35.59 & 187 & 119.29 & 211 & 136.05 & 137 & 16.3 & 124 \\
\hline $\begin{array}{c}\text { Railway and bus } \\
\text { stations, sea ports, } \\
\text { airport stations }\end{array}$ & 0.21 & 53 & 0 & 80 & 1.04 & 76 & 1 & 29 & 20.4 & 51 \\
\hline $\begin{array}{c}\text { Spectacular } \\
\text { entertainment and } \\
\text { sports }\end{array}$ & 0.03 & 42 & 3.5 & 61 & 0.2 & 71 & 3.4 & 77 & 1.5 & 82 \\
\hline
\end{tabular}




\begin{tabular}{|c|c|c|c|c|c|c|c|c|c|c|}
\hline $\begin{array}{c}\text { Religious worship, } \\
\text { sacred }\end{array}$ & 0.08 & 16 & 1.2 & 35 & 0.61 & 16 & 1.2 & 12 & 0 & 21 \\
\hline $\begin{array}{c}\text { Museums, exhibitions, } \\
\text { galleries }\end{array}$ & 0 & 8 & 1.05 & 12 & 0 & 15 & 0.3 & 9 & 0 & 15 \\
\hline Libraries, archives & 0 & 5 & 0 & 2 & 0 & 2 & 0 & 5 & 0 & 7 \\
\hline $\begin{array}{c}\text { Prisons, detention } \\
\text { centers, correction } \\
\text { houses }\end{array}$ & 0 & 1 & 0 & 1 & 0 & 3 & 0 & 4 & 0.5 & 7 \\
\hline Other public facilities & 7.14 & 52 & 0.85 & 66 & 15.4 & 70 & 1.7 & 40 & 0.7 & 75 \\
\hline
\end{tabular}

Signs: $1^{(*)}$ - total water consumption $\left[\mathrm{m}^{3}\right] ; 2^{(*)}$ - number of fires;

Table 4. Number of fires and the total amount of water needed to extinguish fires for residential buildings in $2014-2018$.

\begin{tabular}{|c|c|c|c|c|c|c|c|c|c|c|}
\hline \multirow[b]{2}{*}{ Type of object } & \multicolumn{2}{|c|}{2018} & \multicolumn{2}{|c|}{2017} & \multicolumn{2}{|c|}{2016} & \multicolumn{2}{|c|}{2015} & \multicolumn{2}{|c|}{2014} \\
\hline & $\begin{array}{c}1^{(*)} \\
{\left[\mathbf{m}^{3}\right]}\end{array}$ & $2^{(*)}$ & $\begin{array}{c}1^{(*)} \\
{\left[\mathbf{m}^{3}\right]}\end{array}$ & $2^{(*)}$ & $\begin{array}{c}1^{(*)} \\
{\left[\mathbf{m}^{3}\right]}\end{array}$ & $2^{(*)}$ & $\begin{array}{c}1^{(*)} \\
{\left[\mathbf{m}^{3}\right]}\end{array}$ & $2^{(*)}$ & $\begin{array}{c}\mathbf{1}^{(*)} \\
{\left[\mathbf{m}^{3}\right]}\end{array}$ & $2^{(*)}$ \\
\hline Hotels, night shelters & 0.43 & 46 & 0 & 65 & 0.11 & 64 & 1.41 & 35 & 3.9 & 30 \\
\hline Children's homes & 0 & 4 & 0.02 & 1 & 0.2 & 4 & 0 & 0 & 0 & 3 \\
\hline $\begin{array}{c}\text { Boarding, student } \\
\text { houses }\end{array}$ & 1.2 & 23 & 0.91 & 60 & 0.01 & 79 & 1.1 & 39 & 0.09 & 22 \\
\hline Barrack & 0 & 0 & 0 & 0 & 0 & 0 & 0 & 0 & 0 & 0 \\
\hline Retirement home & 0.4 & 4 & 0 & 4 & 0 & 3 & 0 & 5 & 0 & 1 \\
\hline $\begin{array}{c}\text { Holiday houses, guest } \\
\text { houses }\end{array}$ & 0 & 0 & 0 & 1 & 0 & 2 & 0 & 1 & 0 & 0 \\
\hline Hostels & 0 & 2 & 0.5 & 2 & 0 & 2 & 0 & 1 & 0 & 0 \\
\hline $\begin{array}{c}\text { Single-family houses, } \\
\text { including semi- } \\
\text { detached houses, } \\
\text { terraced houses }\end{array}$ & 224.46 & 254 & 293.71 & 332 & 278.99 & 387 & 620.02 & 309 & 582.22 & 323 \\
\hline Multi-family houses & 222.64 & 3555 & 171.2 & 4331 & 328.13 & 4033 & 327.72 & 4101 & 294.49 & 3730 \\
\hline $\begin{array}{l}\text { Residential buildings } \\
\text { on farms }\end{array}$ & 0 & 3 & 0 & 3 & 1 & 4 & 0 & 1 & 0 & 3 \\
\hline $\begin{array}{l}\text { Other residential } \\
\text { buildings, crew } \\
\text { wagons, cottages }\end{array}$ & 322.63 & 69 & 442.58 & 117 & 523.21 & 131 & 696.45 & 146 & 698.31 & 156 \\
\hline
\end{tabular}

Signs: $1^{(*)}$ - total water consumption $\left[\mathrm{m}^{3}\right] ; 2^{(*)}$ - number of fires;

In the case of residential buildings, the most common were fires of multi-family buildings and single-family buildings. This confirms the thesis that most fires occur in our homes. These are mostly small fires, to extinguish which requires a small amount of water up to $1 \mathrm{~m} 3$. The necessary amount of water to extinguish the fire is primarily influenced by fire-fighting techniques. Reducing the amount of water to extinguish fires through the use of dispersed water currents pulsed is aimed at reducing post-fire losses.

Another element affecting the amount of water consumed during firefighting is the location of fires. Most water is used to extinguish fires occurring on roofs and attics. It is connected with the difficulty of locating this type of fires as well as a large amount of combustible material in the roof structure. In extinguishing operations, about $5 \mathrm{~m}^{3}$ of water was consumed on average. Extinguishing activities carried out at heights from ladders and jacks also required the use of more water to extinguish. This is due to the use of large capacity parcels and nozzles from a large distance. The amount of water used in this case is only a few percent. A relatively large amount of extinguishing water is also needed to extinguish fires in basements, where a large amount of combustible material is accumulated 
and large smoke makes it difficult to locate the source of fire. The least amount of water is used to extinguish fires of flats on higher floors from $0.2 \mathrm{~m}^{3}$ to $0.5 \mathrm{~m}^{3}$. This is influenced by the factors described above, ie limiting the loss after fire and quickly noticing and alerting the fire brigade. . The location of the watchtowers in the area of the capital city of Warsaw is so selected that the time of arrival to any place of possible fire does not last longer than 10 minutes. The activities of preparation and commencement of fire-fighting activities in the facility do not last longer than 5 minutes. Thus, the time of taking firefighting activities from the moment of noticing a fire does not exceed 15 minutes [10]. The dependence of the quantity of extinguishing water on the height of the building is also interesting. Conversely to the predictions, as the height of the building increases, the amount of water used for firefighting purposes decreases [7].

\section{Summary}

A number of requirements that are placed on fire-fighting water installations are aimed at ensuring the reliability of the operation of internal hydrant installations by the users of the facility in the event of a threat. However, it should be remembered that only a wellmaintained and tested installation as well as a conscious and trained user of the facility in the event of a fire will result in an effective fire-fighting action. Unfortunately, it often happens that the installation works only for the reception of the facility by the State Fire Service, and after a few years the unprotected installation is damaged and may not work in the event of a fire. This is confirmed by reports of building users, as well as the experience of firefighters during real incidents. These installations are rarely used and used to extinguish fires in the bud as well as in subsequent extinguishing operations [9].

On the basis of the analysis of fires in residential buildings and public buildings, the most common were small fires. The average amount of water for extinguishing purposes is relatively low and is in the range of $0.5 \mathrm{~m}^{3}-1 \mathrm{~m}^{3}$. This means that to extinguish most fires, also in high-rise buildings, a sufficient supply of water from the tanks of fire-fighting vehicles is sufficient. Actual water consumption indicates that the regulations for watersupply installations are too demanding, which entails high costs for both the implementation of such installations in new buildings as well as in existing buildings. It is not always possible to adapt these buildings to the current requirements of the regulations due to construction and construction reasons. It is therefore necessary to analyze these requirements, especially in tall buildings. The first steps were taken in the amendment of the Regulation in 2010. Therefore, further analysis and liberalization of the provisions on requirements for fire-fighting water installations is necessary.

\section{References}

1. Rozporządzenie Ministra Infrastruktury z dnia 12 czerwca 2002 r. (Dz. U. z 2002 r., Nr 75, poz. 690 z późn. zm.)

2. Rozporządzenia Ministra Spraw Wewnętrznych i Administracji z dnia 7 czerwca 2010r. (Dz. U. Nr 109, poz. 719)

3. S. Kieliszek, T. Drzymała, BiTP 43, 195 (2016)

4. G. Ścieranka, BiTP 48, 124 (2017)

5. T. Łozowski, Instal 4, 32 (2005)

6. G. Ścieranka, Rynek Instalacyjny 9, 84 (2012)

7. S. Kieliszek, T. Drzymała, M. Szutkowski, BiTP 43, 275 (2016) 
8. Andrzej Kamiński, Taktyka działań ratowniczych. Zasady postępowania (CSPSP, Częstochowa, 1998)

9. E. Nowakowski, Rynek Instalacyjny 5, 16 (2013)

10. J. Linder, W. Struś, Ochrona przeciwpożarowa. Budownictwo mieszkaniowe (Instytut Wydawniczy CRZZ, Warszawa, 1979) 